Porter, K. R. (1953). f. exp. Med. 97, 727.

Schneider, W. C. \& Hogeboom, G. H. (195I). Cancer Res. II, I.

Swift, H. H. (1950). Physiol. Zoöl. 23, 169 .

Thomson, R. Y., Heagy, F. C., Hutchison, W. C., \& Davidson, J. N. (I953). Biochem. F. 53, 460.

Vendrely, R. \& Vendrely, C. (1948). Experientia, 4, 434.

\title{
The Influence of the Protein and Energy Content of the Diet on the Liver
}

\author{
By H. N. Munro, Department of Biochemistry, University of Glasgow
}

Pflüger (1903) in the course of a long paper on glycogen claimed that the liver is an organ for the storage of protein. This deduction, for which Pflüger offered only indirect evidence, led his pupil Seitz (1906) to study the nitrogen content of the livers and carcasses of hens and ducks receiving a diet rich in protein. In comparison with fasting birds, the feeding of protein caused the retention of large amounts of nitrogen in the liver, but only slight changes in the total nitrogen content of the carcass. These observations have since been confirmed on other species by a number of investigators (see review by Kosterlitz \& Campbell, 1945-6), the most notable studies being those of Addis, Poo \& Lew (1936a-c). They showed that, when rats undergo a 7 -day fast, the liver loses $40 \%$ of its initial total protein content, the prostate and seminal vesicles $29 \%$ each, the alimentary tract $28 \%$, the kidneys and the drawn blood $20 \%$ each, the heart $18 \%$, the carcass $8 \%$ and the brain $5 \%$; no protein was lost from the eyes, testicles or adrenals. A difference between the proportion of protein lost from the liver and from other tissues was also evident during the first 2 days of feeding a protein-free diet. On re-introducing a large amount of protein into the diet, the liver rapidly increased its protein content but the carcass protein underwent only a small change. A considerable rise in kidney protein on the high-protein diet is attributed by Addis et al. (1936c) to work hypertrophy.

The protein content of the liver is influenced by energy intake as well as by protein intake. Using diets containing substantial amounts of protein, Campbell \& Kosterlitz (1948a) showed that a reduction in energy intake per se reduced the amount of liver protein in proportion to caloric deficit. Munro \& Naismith (I953) confirmed that the total amount of protein in the liver varied linearly with energy intake when the diet provided adequate amounts of protein; however, addition of energy to a protein-free diet tended to reduce the amount of liver protein. On both types of diet, no distinction could be drawn between the effect of energy in the form of carbohydrate or of fat. Comparison of the changes in the liver with those occurring in other tissues showed that energy intake, like protein intake, had a greater effect on the protein content of the liver than on the protein of other tissues generally. The addition of 1000 Cal./sq.m body surface area caused a $23 \%$ increment in liver nitrogen, whereas the other viscera underwent a change of only $3 \%$, and so did the carcass. 
Although these and other experiments establish the considerable sensitivity of liver-protein content to dietary changes, they do not exclude the possibility that the protein content of some of the tissues not separately examined in the comprehensive experiments of Addis et al., such as the pancreas and the mucous membrane of the small intestine, may not be just as greatly influenced by dietary changes. Indeed, White \& Dougherty (r 947 ) found that lymphoid tissue loses a greater amount of nitrogen than the liver during a short fast. These authors have, however, demonstrated that the loss of lymphoid tissue is dependent on the discharge of adrenal cortical hormones during fasting, whereas the loss of liver protein is not.

What significance can be attached to the rapid and extensive fluctuations in the protein content of the liver brought about by variations in diet? The contention that they represent changes in stored protein has prompted investigators to look for a discreet fraction of liver protein in which these variations occur. Luck (1936) separated the proteins of rat liver into four fractions and compared the effect of protein depletion on the total protein content of each fraction. He was unable to demonstrate any appreciable difference in the percentage of protein lost by the different fractions. His experiment accordingly provides no evidence of a chemically discrete store, lost on depletion. This finding has been confirmed by Dumazert \& Grac (1947) using another method of protein separation. A more sensitive method of distinguishing between the effects of depletion on different liver proteins lies in a study of changes in enzyme activity. During the past few years a considerable amount of work has been done on this subject and a recent excellent review is available (Lévy, 1953). The majority of liver enzymes diminish either in proportion to the amount of protein lost from the liver or to a greater extent, xanthine oxidase to virtually zero level. It has been argued (Rosenthal, Rogers, Vars \& Ferguson, 1950) that those enzymes whose concentration diminishes more extensively than does liver protein in general are situated in the labile part of the cytoplasm. There seems, however, to be no single intracellular location in which the more labile enzymes occur (Lévy, 1953). For example, Meikleham, Wells, Richert \& Westerfeld (I95I) studied two of the more labile enzymes, xanthine oxidase and liver esterase, during protein depletion. Xanthine-oxidase activity, which disappeared completely, was entirely located in the cell sap. Esterase activity diminished to $30 \%$ of its initial value; both in normally-fed and in depleted rats $80 \%$ of this enzyme was found in the granules of the liver cell.

Kosterlitz (1947) has examined the changes occurring in other liver-cell constituents during fasting, during protein depletion and on diets rich in protein. These studies and subsequent ones (Campbell \& Kosterlitz, 1949-50) have demonstrated that the changes in total liver protein are closely paralleled by variations in the total amount of phospholipid and, less closely, in the ribonucleic-acid content of the liver. Since these various nutritional conditions did not alter the total number of liver cells, gains and losses were presumed to have occurred through increase or diminution in the amount of cytoplasm. Kosterlitz has therefore given 
the name 'labile liver cytoplasm' to this material. It refers to the protein, ribonucleic acid and phospholipid rapidly gained or lost during the first few days after a change in protein intake. It is thought to represent a concomitant change in the particulate part of the cytoplasm (protein, ribonucleic acid and phospholipid) together with interparticulate protein. The term 'labile liver cytoplasm' thus emphasizes the change in cell substance and not of whole cells. The finding of changes in other liver-cell constituents in addition to protein is taken as telling against deposit or storage protein as the material gained or lost with dietary variations.

Some light is thrown on labile liver cytoplasm by study of the changes occurring in different parts of the liver cell during protein depletion. Wikramanayake, Heagy \& Munro (1953) estimated the total amount of protein, ribonucleic acid and phospholipid in the mitochondrial, microsomal and cell-sap fraction of liver cells from rats of uniform size. Calculations based on these data (Table I) show that protein depletion caused a uniform loss of protein from all cytoplasmic fractions, a loss of ribonucleic acid only from the microsomes, and a diminution in

Table I. Effect of protein deficiency on the total amount of protein, ribonucleic acid and phospholipid in different parts of the liver cell, expressed as a percentage of the amount found in animals receiving protein (calculated from data of Wikramanayake, Heagy $\mathcal{F}^{\circ}$ Munro, 1953). The figures in parentheses are similar calculations based on the combined data of Muntwyler, Seifter $\mathbb{E}^{\circ}$ Harkness (1950) and Seifter, Muntwyler $\mathscr{E}^{\circ}$ Harkness (1950), using the deoxyribonucleic-acid content of their homogenates as a reference standard

$\begin{gathered}\text { Cell } \\ \text { fraction }\end{gathered}$
Nuclei
Mitochondria
Microsomes
Cell sap

\begin{tabular}{ccc}
\multicolumn{3}{c}{ Change caused by protein deficiency } \\
$\overbrace{\text { Protein }}$ & Ribonucleic acid & Phospholipid \\
$(\%)$ & $(\%)$ & $(\%)$ \\
$-(-20)$ & $-(-16)$ & - \\
$-31(-39)$ & $+2(-3)$ & -5 \\
$-36(-43)$ & $-28(-30)$ & -37 \\
$-36(-29)$ & $-7(+8)$ & -38
\end{tabular}

total phospholipid in the microsomes and cell sap. In view of the difficulties of quantitative fractionation of liver cells, it is satisfactory to be able to confirm part of our results by computing the corresponding figures for protein and ribonucleic acid from data published by Muntwyler \& his colleagues (Muntwyler, Seifter \& Harkness, 1950; Seifter, Muntwyler \& Harkness, 1950). By using the deoxyribonucleic-acid content of their whole-liver homogenates as a yardstick of cell number (Davidson, 1954), it is possible to recalculate their data in a form which expresses the total amount of protein and ribonucleic acid in different cell fractions for a standard number of liver cells. In this way it can be shown that the total protein and ribonucleic-acid contents of their liver-cell fractions were affected by protein depletion in the same way as we have observed (see data in parentheses in 
Table I). Thus the material lost from various parts of the liver cell is not uniform in composition.

Since the loss of ribonucleic acid occurs from the microsomes, and these are reputed to be the site of protein synthesis (Siekevitz, I952), it is pertinent to inquire whether this loss could be a contributory cause of less efficient protein synthesis with protein depletion. It has been demonstrated with radioactive phosphorus (Campbell \& Kosterlitz, I948b; Munro, Naismith \& Wikramanayake, I953) that the reduction in total amount of liver ribonucleic acid caused by removal of protein from the diet is counterbalanced by an increased rate of turnover in the remaining molecules, so that the total amount of ribonucleic acid synthesized remains the same as before. More extensive study (Munro, Naismith \& Wikramanayake, I953) of the factors affecting phosphorus uptake by liver ribonucleic acid show that, whereas the amount of ribonucleic acid in the liver is influenced by protein intake, its rate of incorporation of ${ }^{32} \mathrm{P}$ is independent of this factor and is determined by energy intake. Thus, on a diet devoid of protein, increments in energy intake increase the turnover of ribonucleic-acid phosphorus, although they cause little change in the total amount of ribonucleic acid and protein. This effect of energy intake on a protein-free diet affects all parts of the cell, including the microsomes (Wikramanayake, Heagy \& Munro, I953). There is accordingly no reason to believe that the capacity of the liver cell to form ribonucleic acid is a factor limiting the rate of protein synthesis during protein depletion.

The metabolism of phospholipids at low levels of protein intake has also been studied. Campbell \& Kosterlitz (1948b, 1952) have demonstrated that, when the phospholipid content of the liver is reduced by the feeding of a protein-free diet, there is a compensatory increase in phosphorus uptake similar to that occurring with ribonucleic acid. Unlike with ribonucleic acid, however, the rate of synthesis declines after a few days of protein deficiency. At this stage increments in energy intake fail to augment the total rate of phospholipid synthesis, although synthesis on a diet containing protein increases under the same circumstances (Wikramanayake, Munro, Naismith \& Hutchison, 1953).

We have interpreted our findings on the metabolism of protein, ribonucleic acid and phospholipid in the liver cell in terms of two major factors involved in their syntheses, namely building-materials (e.g. amino-acids for proteins) and the necessary energy to link the molecules together (Wikramanayake, Munro et al. 1953). In the normally nourished animal, the amount of energy available may be pictured as the factor determining their rates of formation. During protein deficiency, the supply of amino-acids limits the rate of protein synthesis and addition of energy to the diet can no longer increase the rate of synthesis. With phospholipids, some other component in the synthetic mechanism presumably fails during protein depletion, and sets a limit to the rate of synthesis.

Let us now return to the original problem, why does the protein content of the liver change so much more rapidly and extensively than that of most other tissues? No cogent reason has been advanced for regarding the protein so gained or lost as representing a store, or as being set apart in its intracellular location. Can the 
results be explained in terms of general protein synthesis within the liver? Schoenheimer's (1942) experiments with isotopically labelled amino-acids demonstrate considerable differences in uptake by the protein of different tissues, and it can be demonstrated from his data that the relative rates of amino-acid incorporation in different tissues are in much the same order as the rates of loss or gain of protein by these tissues under the conditions of the experiments of Addis et al. $\left(x_{93} 6 a-c\right)$, referred to above. It has been inferred (Schoenheimer, Ratner, Rittenberg \& Heidelberger, I942) that these figures for amino-acid incorporation reflect corresponding differences in the rates of protein synthesis by these tissues. During fasting or on administration of a protein-free diet, the level of amino-nitrogen in the plasma falls below the average daily level on a diet containing protein. It is not, however, reduced to zero (Wu, r954). If, as the isotopic data suggest, the life of the average liver protein is considerably less than that of the average muscle protein, then the protein content of the liver will become adjusted rapidly to the new blood amino-acid level, giving the impression of being more labile than the protein of other tissues. This condition seems to apply to most, if not all, of the liver proteins. For example, some data in the literature (Appleman, Skavinski \& Stern, 1950; Kochakian, Bartlett \& Moe, I948; Westerfeld, Richert \& Hilfinger, I950) allow us to compare the total amount of the same enzyme in liver and in other tissues during protein depletion. In all instances where a fall in liver-enzyme content occurred, the effect on the enzyme in the liver was much greater than on the same enzyme in another organ. It may be concluded that the lability of liver enzymes is a characteristic of protein metabolism in the liver and not of the enzyme as such. The factors responsible for differences in protein metabolism of different tissues remain obscure.

\section{REFERENCES}

Addis, T., Poo, L. J. \& Lew, W. (1936a). f. biol. Chem. r15, г I I. Addis, T., Poo, L. J. \& Lew, W. (1936b). F. biol. Chem. I15, I I 7 . Addis, T., Poo, L. J. \& Lew, W. (1936c). F. biol. Chem. I16, 343. Appleman, D., Skavinski, E. R. \& Stern, A. S. (1950). Cancer Res. 1o, 498. Campbell, R. M., \& Kosterlitz, H. W. (1948a). F. Physiol. 1o7, 383 .

Campbell, R. M. \& Kosterlitz, H. W. (1948b). F. biol. Chem. 175, 989.

Campbell, R. M. \& Kosterlitz, H. W. (1949-50). F. Endocrin. 6, 308.

Campbell, R. M. \& Kosterlitz, H. W. (1952). Biochim. biophys. Acta, 8, 664.

Davidson, J. N. (1954). Proc. Nutr. Soc. 13, I I2.

Dumazert, C. \& Grac, S. (1947). Arch. Sci. Physiol. I, 339.

Kochakian, C. D., Bartlett, M. N. \& Moe, J. (1948). Amer. F. Physiol. r54, 489.

Kosterlitz, H. W. (1947), F. Physiol. 106, 194.

Kosterlitz, H. W. \& Campbell, R. M. (1945-6). Nutr. Abstr. Rev. I5, I.

Lévy, M. (1953). Ann. Nutr., Paris, 7, 167.

Luck, J. M. (1936). F. biol. Chem. Ir5, 49 I.

Meikleham, V., Wells, I. C., Richert, D. A. \& Westerfeld, W. W. (195I). J. biol. Chem. r92, 65 I.

Munro, H. N., \& Naismith, D. J. (I953). Biochem. F. 54, I9I.

Munro, H. N., Naismith, D. J. \& Wikramanayake, T. W. (1953). Biochem. $\mathscr{F} .54$, I98.

Muntwyler, E., Seifter, S. \& Harkness, D. M. (1950). F. biol. Chem. 184, 181.

Pflüger, E. (1903). Arch. ges. Physiol. 96, I.

Rosenthal, O., Rogers, C. S., Vars, H. L. \& Ferguson, C. C. (1950). F. biol. Chem. 185, 669.

Schoenheimer, R. (1942). The Dynamic State of Body Constituents. Cambridge, Massachusetts: Harvard University Press.

Schoenheimer, R., Ratner, S., Rittenberg, D. \& Heidelberger, M. (1942). F. biol. Chem. 144, 541. 
Seifter, S., Muntwyler, E. \& Harkness, D. M. (1950). Proc. Soc. exp. Biol., N.Y., 75, 46.

Seitz, W. (1906). Arch. ges. Physiol. III, 309.

Siekevitz, P. (1952). F. biol. Chem. 195, 549.

Westerfeld, W. W., Richert, D. A. \& Hilfinger, M. F. (1950). Cancer Res. 10, 486.

White, A. \& Dougherty, T. F. (1947). Endocrinology, 4r, 230.

Wikramanayake, T. W., Heagy, F. C. \& Munro, H. N. (1953). Biochim. biophys. Acta, II, 566.

Wikramanayake, T. W., Munro, H. N., Naismith, D. J. \& Hutchison, W. C. (1953). Biochem. F. 55, 640.

Wu, C. (1954). F. biol. Chem. 207, 775 .

\section{The Influence of Diet, Environment and other Factors on Experimental Liver Necrosis in the Rat}

\section{By J. M. Naftalin, Rowett Research Institute, Bucksburn, Aberdeenshire}

This paper deals with factors affecting the sensitivity of rats to the development of acute dietary liver necrosis. The sensitivity is influenced by the way the diet is fed (to appetite or restricted) as well as by the chemical composition of the diet, the environment, the age at weaning and other factors.

\section{Chemical composition of the diet}

Weichselbaum (I935) was the first to report acute damage ('haemorrhages') in the liver as a result of feeding a low-protein diet to rats. The diet was similar to that described by Sherman \& Merrill (I925) and contained dried whole-milk powder 16.6 , corn (maize) starch 80.6 and salt mixture $2.8 \%$. Four drops of codliver oil and $75^{-1} 5^{\circ} \mathrm{mg}$ Marmite were given to each rat daily. Sherman \& Merrill did not report liver lesions or deaths.

During the course of the next few years several independent reports from America, Britain and Germany described acute liver necrosis in the rat as the result of feeding poor diets. By 1949 it was generally believed that deficiency both of sulphur-containing amino-acids and of vitamin $\mathrm{E}$ was necessary to produce the lesions. The former deficiency was usually achieved by feeding rats on diets low in casein (5-10\%) (Schwarz, 1944; Himsworth \& Glynn, 1944-5; György \& Goldblatt, I949; Hove, Copeland \& Salmon, 1949) or on diets in which the sole source of protein was yeast (Hock \& Fink, I943; Himsworth \& Glynn, 1944-5; Schwarz, 1948; Abell \& Beveridge, 1949). However, György \& Goldblatt (1939, I949) found that liver necrosis either did not appear or was reduced in incidence when a yeast diet was fed, or when yeast was added to their casein diet. It has now been suggested that these discrepancies were due to differences in the yeast used (György, Rose, Tomarelli \& Goldblatt, 1950; György \& Goldblatt, I95 I ; Schwarz, 1951, 1952). That caseins also differ in their capacity to induce liver necrosis has been reported by Schwarz (1944), Hove, et al. (1949), and Naftalin $(1954 b)$; this topic is discussed later in this paper.

György \& Goldblatt (I949) suggested that liver necrosis could be produced 